2018-03-15

\title{
Knowledge and the study of education: an international comparison
}

\author{
Kelly, Peter
}

http://hdl.handle.net/10026.1/12957

10.1080/02607476.2018.1436816

Journal of Education for Teaching

Informa UK Limited

All content in PEARL is protected by copyright law. Author manuscripts are made available in accordance with publisher policies. Please cite only the published version using the details provided on the item record or document. In the absence of an open licence (e.g. Creative Commons), permissions for further reuse of content should be sought from the publisher or author. 


\section{Knowledge and the study of education: an international comparison}

\section{Peter Kelly}

To cite this article: Peter Kelly (2018): Knowledge and the study of education: an international comparison, Journal of Education for Teaching, DOI: 10.1080/02607476.2018.1436816

To link to this article: https://doi.org/10.1080/02607476.2018.1436816

曲 Published online: 07 Feb 2018.

Submit your article to this journal $[\pi$

Q View related articles $\sqsubset$

View Crossmark data \lceil 
BOOK REVIEW

\section{Knowledge and the study of education: an international comparison, by Geoff} Whitty and John Furlong, Oxford, Symposium Books, 288 pp., $£ 42$ (paperback), ISBN 978-1-873927-97-7

The publication of Michael Young's Bringing Knowledge Back In in 2008 brought renewed interest in the status of knowledge in the sociology of education. Knowledge and the Study of Education builds on Young's work to provide a comparative analysis of knowledge traditions in education studies, each set within changing socio-political contexts. For example, in recent years a number of alternative approaches and viewpoints have undermined the central role of universities in teacher education in England and the USA. This book builds on the findings of a project that conducted an historical and comparative analysis of the knowledge traditions underpinning education scholarship and research, including their links to teacher education, in different countries. These included Australia, China, France, Germany, Latvia and the USA, with England included in later chapters, providing a fascinating range of histories and traditions of education scholarship for consideration. The result is an interesting, original and convincing account, which, I am sure, will appeal widely.

The book is in four parts. An overview written by the two editors, which maps different traditions in the study of education is followed by six case studies written by expert contributors from each of six jurisdictions. There are four chapters in the next section, which explore conceptual frameworks for understanding and analysing the various traditions identified in education as a field of study. Finally, an afterword by David Labaree makes sense of the earlier chapters and identifies future prospects for the study of education in universities. Whilst all will be of interest to the general reader as well as comparative education scholars and researchers, here I will focus briefly on the first and final chapter and four of those from the two parts in between.

In their introductory chapter, the book's editors, Geoff Whitty and John Furlong, identify twelve major knowledge traditions in the study of education, classifying these as Academic Knowledge Traditions, Practical Knowledge Traditions and Integrated Knowledge Traditions. Drawing on Basil Bernstein's $(1996,1999)$ analysis, they divide academic traditions into'singulars', comprising the sub-disciplines of the sociology, psychology, history and philosophy of education that once dominated education studies in the UK, the Sciences de I'Education in France and hermeneutic-philosophical German educational thought. They identify the German stance as differing from those in the UK and France because it assumes a distinctively educational form of thinking, but the strength of all three and the reason for their singularity is that they are clear but distinct substantive bodies of thought with associated verification and legitimation protocols. Their drawback lies in the single-mindedness of their perspective and their perceived distance from educational practice. A second category of academic tradition, what Bernstein calls'regionals', is best thought of in terms of medicine, where singular disciplines are recontextualised into larger units whilst retaining a common and coherent approach to verification and legitimation. In this category is what the editors refer to as the new science of education, which promises to find out 'what works' through the application of rigorous research, typically in the form of randomised controlled trials and systematic reviews. This follows knowledge traditions that consider the study of education to be most effective when tackled using methods taken from the natural sciences. Both singular 
and regional academic knowledge traditions are contrasted with practical knowledge traditions, amongst them the 'competencies and standards' model ascendant under neoliberalism, where the authority of persuasive ideas and value positions, of rigorous research, argument and evidence or of debate and consensus is replaced by faith in emergent knowledge, which evolves through the workings of an 'invisible hand'. Finally, there are integrated knowledge traditions which try to bring the academic and the practical together. These include action research, which aims improve professional practice by looking at it though disciplinary lenses, and practitioner inquiry, which seeks to use understandings and methods taken from academic research in order to improve practice. This categorisation, which is extremely useful, then forms a thread linking the various chapters in the rest of the book.

Chapters follow which analyse education studies in six countries. All are thought-provoking, but I particularly found interesting those providing insights into traditions not widely discussed in the English language literature. Jürgen Schriewer's chapter, for instance, gives a fascinating account of the development and nature of education studies in Germany. Debate between hermeneutic-philosophical scholars and those engaged in experimental psychology and pedagogy in the first decades of the twentieth century left the former ascendant, and explain the continuing resistance shown by some proponents of Germany educational thought towards empiricist approaches. Irēna Žogla's chapter on Pedagogija, describes the rich and complex Latvian education discipline, based in a particular view of the holistic nature of human development, which implies engagement with the whole learner. Yet, as is the case in other jurisdictions, newer education science perspectives are challenging this longstanding knowledge tradition.

We then move to conceptualising and theorising education as a field of study. Along with those focussing on the English context, there are two comparative chapters here. Dina Kuhlee and Christopher Winch present three ideal types of teachers as knowledgeable practitioners, the craft worker, the executive technician and the professional technician, and assert that the first dominates in England whilst that of professional technician dominates in Germany. This analysis is situated in the cultural and political contingencies of each country. Maria Teresa Tatto and Jim Hordern analyse the role of education studies in secondary teacher education in Germany, Poland, Singapore and the USA, focusing particularly on mathematics, and identify how curricula in each case are recontextualised in relation to national factors. For example, in Singapore, where notions of mathematics teachers' professional competence are controlled centrally, teacher education tends to emphasise teaching as the application of technical protocols, whereas approaches to teacher education in Germany, Poland and the USA are much more varied, include social alongside academic guidance and provide some consideration of how to address the varying needs of diverse groups of students.

Finally, addressing futures of the field of education, David Labaree usefully identifies broad elements of commonality between the chapters. These include common tensions between normative views of education as value-laden and objective views which look to identify the knowledge and skills needed by society, between knowledge embedded in context, what Durkheim calls the profane, and that abstracted or sacred, and between the organisation of educational knowledge as sub disciplines and that of regarding education as a field in its own right. He then raises a fourth consideration - that of educational purpose. This seems to me to be highly important. That education is primarily an economic imperative is a relatively recent view, and certainly one which the 'what works' empiricism of new educational science takes for granted. As many of the chapters show, this view has, to some extent, sidelined more humanistic arguments for education as a good in its own right. It should be of concern to us all when one view of educational purpose becomes hegemonic; more so when utilitarianism dominates to the extent that it eclipses the value of education in helping people make sense of their lives and the world in which they live.

This is an excellent book, which, I am sure, will be of value to both those directly interested in comparative education and a wider readership. Making, as it does, an important contribution 
to the comparative history of the study of education, I have no doubt that it will encourage a broader engagement with the nature of the education field.

\section{References}

Bernstein, B. 1996. Pedagogy, Symbolic Control and Identity: Theory, Research, Critique. London: Taylor Francis.

Bernstein, B. 1999. "Vertical and Horizontal Discourse: An Essay." British Journal of Sociology of Education 20 (2): $157-173$.

Young, M. 2008. Bringing Knowledge Back In: From Social Constructivism to Social Realism in the Sociology of Education. London: Routledge.

Peter Kelly

Plymouth University, UK peter.kelly@plymouth.ac.uk

(c) 2018 Peter Kelly https://doi.org/10.1080/02607476.2018.1436816 